IJGE

14,1

Received 15 January 2021

Revised 27 April 2021

24 June 2021

15 July 2021

Accepted 20 July 2021

\section{Aged and gendered master narratives on entrepreneurship in Finnish higher education}

\author{
Päivi Tuulikki Siivonen \\ School of Educational Sciences and Psychology, University of Eastern Finland, \\ Joensuu, Finland, and \\ Katri Komulainen, Kati Kasanen and Paula Kupiainen \\ University of Eastern Finland, Joensuu, Finland
}

\begin{abstract}
Purpose - The purpose of this paper is to examine the construction of master narratives related to age, gender and entrepreneurship in the context of entrepreneurship education (EE) in Finnish higher education (HE). This is important as master narratives create and limit our understanding of entrepreneurship.

Design/methodology/approach - The data comprises 30 student interviews generated in one multidisciplinary Finnish university. The data were analyzed using narrative positioning analysis to examine what kinds of master narratives are (re)constructed in relation to age and entrepreneurship by Finnish university students and how gender intertwines with age in the construction of entrepreneurship.

Findings - Three aged and gendered master narratives were identified: (1) youthful, masculine, startup/ growth entrepreneurship; (2) middle-aged feminine, expert entrepreneurship and (3) modest, feminine, senior entrepreneurship. The paper makes visible aged and gendered master narratives and cultural norms related to entrepreneurship in the context of $\mathrm{EE}$ and $\mathrm{HE}$. Authors argue that the youthful, masculine startup/growth entrepreneurship is the hegemonic master narrative in the context of EE in Finnish HE. Femininity is mostly excluded from this master narrative.

Originality/value - The paper contributes to critical literature on entrepreneurship as an aged as well as gendered phenomenon in the context of EE and HE. So far research on entrepreneurship as an aged and gendered phenomenon in EE and in the context of $\mathrm{HE}$ has been virtually non-existent. Moreover, the theoretical and methodological focus on master narratives in entrepreneurship and EE literature is novel. The master narratives identified in the study show that $\mathrm{HE}$ students are not addressed equally in relation to entrepreneurship, but aged and gendered hierarchies are sustained.
\end{abstract}

Keywords Higher education, Entrepreneurship education, Entrepreneurship, Master narrative, Age, Gender Paper type Research paper

\section{Introduction}

Entrepreneurship has become a key issue and a basic competence on the European educational and labor market policy agenda (Bacigalupo et al., 2016). In supranational higher education (HE) policy, entrepreneurship is promoted through entrepreneurship education (EE) for all students across all disciplines (European Commission, 2008), but particularly within technical fields of education in which the potential for economic growth is greatest (Laalo et al., 2019). Among European countries Finland has been at the forefront of promoting

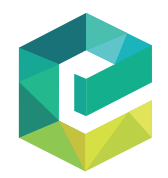

International Journal of Gender and Entrepreneurship Vol. 14 No. 1,2022 pp. $26-43$

Emerald Publishing Limited $1756-6266$

DOI 10.1108/IJGE-01-2021-0010
(C) Päivi Tuulikki Siivonen, Katri Komulainen, Kati Kasanen and Paula Kupiainen. Published by Emerald Publishing Limited. This article is published under the Creative Commons Attribution (CC BY 4.0) licence. Anyone may reproduce, distribute, translate and create derivative works of this article (for both commercial and non-commercial purposes), subject to full attribution to the original publication and authors. The full terms of this licence may be seen at http://creativecommons.org/licences/by/4.0/ legalcode

This work was supported by the Academy of Finland under Grant number 295961 and Grant number 315796. 
entrepreneurship on all educational levels from preschool to university (Komulainen, 2006; Siivonen and Brunila, 2014). Especially after the recession in the 1990s, entrepreneurship has started to permeate the whole Finnish educational system (Komulainen, 2006). Throughout the 2000s entrepreneurship has become increasingly associated with startups and growthorientated businesses (Hyrkäs, 2016). Startup entrepreneurship has also become part of the Finnish HE-political agenda and expectations concerning $\mathrm{HE}$ graduates are on knowledgeintensive growth or startup entrepreneurship (Laalo et al., 2019).

Despite the HE policy agenda of promoting entrepreneurship for all students, former literature has shown that entrepreneurship is a gendered, raced and classed category that is shaped in ways that legitimize some entrepreneurs while marginalizing others (see, e.g. Ogbor, 2000; Komulainen, 2006; Komulainen et al., 2009; Hytti and Heinonen, 2013; Gill, 2014; Jones, 2014, 2015; Komulainen et al., 2020). Nonetheless, so far, research on age and entrepreneurship (see, however, Ainsworth and Hardy, 2008) as well as age and gender in relation to entrepreneurship has been scarce (see, however, Tomlinson and Colgan, 2014; Lewis, 2017) and virtually non-existent in the context of EE and HE. This study contributes to critical literature on entrepreneurship as an aged and gendered phenomenon in the context of $\mathrm{EE}$ and Finnish $\mathrm{HE}$ and focuses on the construction of master narratives related to age, gender and entrepreneurship, which is a novel theoretical and methodological approach in entrepreneurship and EE literature. By master narratives we refer to normative cultural expectations, i.e. how life ought to be lived in the culture (Phoenix, 2008).

The justification for educating business-orientated university graduates capable of employing themselves and others is the positive impact of their entrepreneurial activity on the economy (Laalo et al., 2019). Growth and productivity are the key notions associated with entrepreneurship (Dahlstedt and Hertzberg, 2012). Interestingly, however, only 8\% of university-educated young people in Finland wish to work as entrepreneurs (Akava, 2016). Moreover, in Finland entrepreneurial intent is also more common for males than females (Räty et al., 2019). All in all, university graduates may not be interested in entrepreneurship as academic wage work provides independence and challenges, they lack role models, entrepreneurship has a low social status among them or they do not share the values related to entrepreneurship (Komulainen et al., 2019).

The objectives of EE in universities have been perceived as three-fold (Heinonen and Hytti, 2010): Teaching about entrepreneurship (studying entrepreneurship as an academic subject), teaching through entrepreneurship (the training of an entrepreneurial workforce) and teaching for entrepreneurship (acquiring the skills needed in businesses). In this study we focus on the last dimension, that is, entrepreneurship as venture creation and how it is viewed and talked about by university students. In addition to the academic curriculum, learning opportunities that take place informally outside the classroom is also an important feature of EE (Rae et al., 2012; Siivonen et al., 2019).

In Europe, including Finland, the workforce is ageing rapidly and there is also an urgent need to satisfy the labor market of the future by prolonging careers at the beginning, middle and end (see Siivonen and Isopahkala-Bouret, 2016). Young people as the future workforce are particularly encouraged to become entrepreneurial and start businesses (Laalo et al., 2019). However, entrepreneurship is not only promoted for young people but for all ages (Tomlinson and Colgan, 2014; Kautonen et al., 2017). For people aged 50 +, starting up in business may be the only alternative to prolonging their working lives due to discriminatory practices in recruitment or a lack of attractive employment options (Kautonen et al., 2011).

We understand age as a social construction and ageing as a lifelong process (see e.g. Tomlinson and Colgan, 2014; Siivonen and Isopahkala-Bouret, 2016). Thereafter, our analysis does not focus on chronological age or any particular age group, but instead, we are interested in the construction of age, gender and entrepreneurship of female and male university students aged 22-65 years and representing different disciplines in our interview data. 
IJGE

14,1

In this study we examine entrepreneurship as a social process in the context of EE and HE and ask (1) What kinds of master narratives are (re)constructed in relation to age and entrepreneurship by Finnish university students? (2) How does gender intertwine with age in the construction of entrepreneurship? We will first discuss the construction of ideal entrepreneurs. We will then discuss the concept of master narrative, present our interview data and the narrative positioning method of analysis. Thirdly, we will present our results, the construction of three master narratives on entrepreneurship that are both aged and gendered. We will conclude with some final remarks on how the master narratives limit our cultural understandings of entrepreneurship and the implications of our findings in the context of $\mathrm{HE}$.

\section{The construction of ideal entrepreneurs}

Entrepreneurship is constructed in line with the neoliberal individualistic discourse that emphasizes individual responsibility, autonomy, self-confidence, continuous selfdevelopment, flexibility, activity, risk-taking, initiative, problem-solving, decision-making, creativity and innovativeness, as well as passion and dedication (e.g. Dahlstedt and Hertzberg, 2012; Farny et al., 2016; Villasana et al., 2016; Laalo et al., 2019). It is justified in terms of a freely chosen, optimistic occupational choice for everyone (Gill, 2014). Entrepreneurship is thus naturalized, normalized and neutralized; it is depicted as being available for all; everyone is included as long as they choose the right kind of entrepreneurial mentality and mindset (e.g. Berglund, 2013; Jones, 2014). Adopting entrepreneurship as a mindset is a way of ascertaining one's employability, the ability to become employed, in an increasingly competitive and uncertain labor market (Brine, 2006).

However, prior studies worldwide, as we indicate below, have shown that entrepreneurship is a rather restrictive category to which only a few special individuals have access. An ideal entrepreneur is associated with youth, middle-classness and masculinity (Komulainen, 2006; Ainsworth and Hardy, 2008; Komulainen et al., 2009; Hytti and Heinonen, 2013; Gill, 2014; Whiting and Pritchard, 2020). Villasana et al. (2016) showed that Latin American male students reported feeling more creative and better at managing problems and risks than women, and thus indicating greater potential as entrepreneurs. Likewise, Yukongdi and Lopa (2017) showed that female university students in Asia perceived being an entrepreneur as significantly more unacceptable than male students and suggest that this reflects the masculine norms and values associated with entrepreneurship. As a consequence, young women are prevented from viewing entrepreneurship as an attractive and feasible career option due to gender stereotypes and the masculine construction of entrepreneurship (Jones, 2015; Byrne et al., 2019). Moreover, based on their study of older workers in Australia, Ainsworth and Hardy (2008) argue that entrepreneurship is an inherently aged construction and is not equally accessible to all age groups. "Olderpreneurs" may even lack the narrative resources to support their identity work (Mallett and Wapshott, 2015).

In the US context, Gill (2014) argues in a similar vein that entrepreneurial discourse reproduces class hierarchies and that legitimate entrepreneurship is for the creative, experienced, white, professional middle and upper classes. Entrepreneurs are constructed as owners and supporters of capitalist growth; they are individuals who bring innovative, technological and high-growth ideas to the market. They are constructed as special people (Hytti, 2005), compared to wage workers (Komulainen et al., 2020). Similarly, Jones (2015) argues based on her study on UK university teachers and students that the shared cultural understanding of entrepreneurship is associated with such masculinized traits as risk-taking and continuous search for opportunities to make money that only special people possess. In this cultural realm young females aspiring to business ownership positioned themselves as just business owners and not "true" entrepreneurs. Femininity was incompatible with the ideal and proper entrepreneur delineated in the EE module that they had attended. 
The masculine construction of entrepreneurship sets the norm for the ideals of a growthorientated entrepreneur (Ahl and Marlow, 2021). Feminine characteristics are excluded from these ideals. Hytti and Heinonen (2013) identified two distinct entrepreneurial identities in their study of a Finnish university entrepreneurship training program for life sciences in the field of high-tech: the heroic and humane entrepreneur. Male participants in their study found it easy to identify with the heroic image of a risk-taking, courageous, successful male entrepreneur. The female participants, on the other hand, identified themselves with the image of a humane entrepreneur and running a low-tech firm with modest business goals or in areas other than their own field of study. They were unable to view themselves as high achievers akin to successful men. Hytti and Heinonen (2013) argue that the realm of high-tech life science entrepreneurship is particularly masculine and consequently a more challenging arena for women. As Komulainen et al. (2009, p. 646) suggest "the kind of innovative, risktaking expert entrepreneurship that reforms the society and secures the nation's competitive power is reserved for males that opt for academic education in the technological fields". Thus, a proper entrepreneur is a male who is continuously engaged in the active, dynamic and competitive risk-taking pursuit of economic opportunity to maximize profit and growth.

So far, however, we know little about age and how it intertwines with gender in relation to entrepreneurship in the context of HE. Moreover, Finland provides a fruitful context to study age and entrepreneurship as Finnish students are older than university students in many countries and represent different age groups (Lindberg, 2009). Against this backdrop it is important to address the gap in literature related to age, gender and entrepreneurship in the context of $\mathrm{EE}$ in Finnish $\mathrm{HE}$ and examine what kinds of master narratives on entrepreneurship in relation to both age and gender are (re)constructed by different aged female and male university students. The analysis of master narratives contributes to the literature in an important way as it is a novel theoretical and methodological approach of addressing age, gender and entrepreneurship in the context of $\mathrm{EE}$ and $\mathrm{HE}$.

\section{Methodological issues}

This study explores entrepreneurship as a socially constructed phenomenon produced in interview interaction in a shared narrative environment (Gubrium and Holstein, 2008) of one multidisciplinary Finnish university. We examine the construction of master narratives on entrepreneurship in relation to age and gender, that is normative cultural expectations (Phoenix, 2008) related to entrepreneurship in the context of EE and HE. Similarly, to De Fina (2013), we understand master narratives as dominant ideas and systems of ideas produced and reproduced through varieties of discursive and non-discursive social practices and not necessarily constituting coherent systems, but rather as being in flux. The analysis of master narratives is fruitful as it enables "theorizing narrative structure (pre-existing narrative scripts) and action (telling a narrative) within the same conceptual frame" (Hyvärinen et al., 2021, p. 98). Master narratives are, thus, relevant as "actively used resources within the ongoing action” (Hyvärinen et al., 2021, p. 118). Meanings of entrepreneurship and age as well as gender are negotiated, contested and reflect the surrounding social and physical environment.

This article focuses on individual student interviews. The data were generated as part of a larger project on academic entrepreneurship from 2016 to 2017 at one Finnish university. As part of the larger project we also generated ethnographic data (field notes, photos, documents, online data) from a four-day EE course that was aimed at students studying at the same university as well as the University of Applied Sciences (UAS) [1] located in the same university town - which adds to the familiarity of the community (De Fina, 2013). As De Fina (2013) argues, the interpretation of interviews can be supported through ethnography to interpret narrative patterns beyond the local context that have a more general significance. 
IJGE

14,1

Our ethnographic study (Komulainen et al., 2020) based on the aforementioned ethnographic dataset showed that entrepreneurship is offered as a career option for all, but that young middle-class male university students are regarded as having greater potential for success in business and in working life. This finding urged us to study further how female and male university students representing different age groups construct age, gender and entrepreneurship.

The data of this study comprises 30 individual interviews with university students generated by Authors 1,2 and 3. The themes covered the pathway to university, the meaning of academic education, experiences of $\mathrm{EE}$ and conceptions of entrepreneurship, work experience and how university contributes to entrepreneurship and employability. Conceptions of entrepreneurship were also discussed through value statements and a role-playing method. The participants represented different disciplines from the beginning to the final studying phase. The duration of the narrative life historical interviews varied from around 1.5 to four hours. The interviews were recorded and transcribed verbatim. They were conducted and analyzed in Finnish. The interview quotes presented in this article were translated into English by Author 1.

The interviewees were recruited through EE courses and a survey on students' perceptions of their employability and entrepreneurial intent that was conducted as part of the larger project (results from the survey were reported elsewhere, see e.g. Räty et al., 2019). Recruitment of interviewees through EE courses and a survey targeted at students who represented different disciplines and age groups enabled us to ensure the multivoicedness of the data. 20 of the students were females and 10 males. The age range was between 22 and 65 years. 18 of the interviewees were aged between 20 and 29 years, eight of them were 30-39 years and four of them were over 40 years of age. 10 of the interviewees considered venture creation as a possible future career option for themselves, while others did not consider it their primary option (see Table 1). All the interviewees, however, participated in the meaningmaking on entrepreneurship. Interviewees had been exposed to EE in diverse ways: by attending EE courses, by being taught by entrepreneurs as part of their major or minor subjects or by making work projects for real or imagined enterprises as part of their course work. They had also visited enterprises or participated in EE informally outside the academic curriculum.

Based on the aforementioned interview data we have formerly identified three narrative identity positions, namely, academic experts (emphasized academic education and careers), multitalents (focused on employability by developing varied skillsets) and entrepreneurs (considered entrepreneurship as a possible future career option) (Komulainen et al., 2019). The focus of this study is not on individual students' identity positions but on the (re)construction of master narratives as culturally shared understandings. Moreover, the current study focuses on meanings constructed in relation to age and gender, which was not the focus of the aforementioned study.

To analyze and interpret the master narratives we applied the small story approach and level 3 of the three-level narrative positioning analysis (Bamberg, 1997, 2004; De Fina, 2013; Hyvärinen et al., 2021). Small stories refer to short narratives, descriptions or fragments of speech about past, present and future incidents (Bamberg and Georgakopoulou, 2008) produced in social interaction in a shared narrative environment (Gubrium and Holstein, 2008). The level 3 positioning analysis focuses on the close reading of both the story world (level 1) and the telling (level 2) of the story. The former refers to how the characters of the story are constructed: how they position themselves and are positioned in relation to each other so that at this level we are able to analyze what the story is "about" (Bamberg, 1997, 2004). The level 2 analysis focuses on how the narrator positions her/himself in relation to the audience in the interaction of telling the story (Bamberg, 1997). In other words, what is the narrator trying to accomplish with the story (Bamberg, 2004)? The level 3 analysis involves 


\begin{tabular}{|c|c|c|c|c|c|}
\hline Pseudonym & Gender & Age & Major subject & Venture creation as a career option (Yes/No) & Aged and \\
\hline Aaron & Male & 28 & Business sciences & Yes & master \\
\hline Adam & Male & 20 & Biology & No & \\
\hline Alisa & Female & 24 & Law & Yes & narratives \\
\hline Amelia & Female & 42 & Health sciences & No & \\
\hline Anni & Female & 65 & Law & Yes & \\
\hline Bella & Female & 36 & Social work & No & 31 \\
\hline Dani & Male & 22 & Applied physics & No & \\
\hline Diana & Female & 24 & Education & No & \\
\hline Donna & Female & 29 & Business sciences & No & \\
\hline Ella & Female & 31 & Social work & No & \\
\hline Eljas & Male & 23 & Biology & No & \\
\hline Emma & Female & 26 & Business sciences & Yes & \\
\hline Eric & Male & 25 & Business sciences & No & \\
\hline Jasmin & Female & 28 & Business sciences & No & \\
\hline Jasper & Male & 26 & Geography & No & \\
\hline Laura & Female & 25 & Social sciences & No & \\
\hline Leila & Female & 41 & Business sciences & Yes & \\
\hline Linda & Female & 31 & Bio science & Yes & \\
\hline Linnea & Female & 50 & Social pedagogics & No & \\
\hline Lisa & Female & 24 & Social sciences & Yes & \\
\hline Mia & Female & 25 & English and translation & Yes & \\
\hline Pete & Male & 49 & Mathematics & No & \\
\hline Rebecca & Female & 30 & Business sciences & No & \\
\hline Reetta & Female & 26 & Social sciences, forestry & Yes & Table 1 \\
\hline Robert & Male & 37 & Guidance and counseling & No & The interviewees' \\
\hline Sami & Male & 32 & Computer sciences & No & pseudonvms, gender. \\
\hline Sebastian & Male & 23 & Business sciences & Yes & age, major subject and \\
\hline Siiri & Female & 28 & History & No & positioning toward \\
\hline Vanessa & Female & 24 & Mathematics & No & venture creation as a \\
\hline Victoria & Female & 37 & Social work & No & possible career option \\
\hline
\end{tabular}

connecting what is said at the local level with general tendencies in the way in which issues are viewed and dealt with by the communities to which the individuals belong (De Fina, 2013). This implies the analysis of narrative positioning "vis-à-vis cultural discourses and normative (social) positions, either by embracing them or displaying neutrality, or by distancing, critiquing, subverting, and resisting them" (Bamberg, 2004, p. 6). An analysis of how narrators use culture requires going beyond what narrators say in order to recognize how they draw on the wider culture (Phoenix, 2008).

In our analysis the focus was on the level 3 analysis as it is important to deal with how narrators and audiences construct and negotiate culturally shared master narratives, which also include moral statements (Bamberg, 1997, 2004; De Fina, 2013). In order to focus on the level 3 analysis, we also read the level 1 and level 2 positioning. In practice, we first read through the interview data carefully and coded the small stories where entrepreneurship and age and gender in relation to entrepreneurship were talked about. Second, we applied the three-level positioning analysis with the focus on the level 3. Analytically positioning at different levels is separate but in practice the boundaries are fluid and the same instances of language use relate to different levels of positioning (Bamberg, 2004).

As suggested by De Fina (2013), we paid careful attention to language and how it was used in the data by reading and interpreting the repetition of storytelling actions (e.g. a possibility of starting a business), positions (e.g. promotion, neutrality, critique or resistance toward entrepreneurship) and other elements across storytellers and stories that pointed to the 
IJGE

14,1

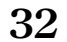

32

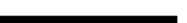

\section{pro}

possibility of significance beyond the level of particular interactions to the collective positioning processes. We read such language use as "risk-taking", "profit-seeking", "growth orientation" and "competition". We also paid attention to how education and work experience were talked about in relation to entrepreneurship and what kinds of skills and characteristics were considered as important for an entrepreneur. Thus, the comparison of data from different participants and the search for meaningful patterns constituted an integral part of our interpretive work. Familiarity with the community and the comparison of recurring patterns between different participants within the community contributed to a more profound reading and interpretation of the data (De Fina, 2013).

In our analysis of interview data, we read and interpreted social distinctions (age, gender) that are understood here as being narrative, material and embodied. Age and gender are seen as socially constructed processes that are lived on a daily basis (see Reay, 2006). They form crosscutting and mutually reinforcing systems of domination and subordination (Anthias, 2005), including some, while excluding others (Skeggs, 2005). Social differences materialize as different types of socially valued resources that position individuals differently in terms of social categories (see Skeggs, 1997; Anthias, 2005).

A dominant master narrative related to age in Western societies is the narrative of decline. It is a downward, regressive storyline related to loss, pain and disability that affects habits, identities, ways of seeing bodies and affects (Gullette, 2003). A narrative of progress, on the other hand, relates to active, productive and successful ageing. It is often presented as a counter narrative to the narrative of decline. The norm of middle age is the middle-aged individual at the peak of their workplace power and is the implicit comparison group for the narrative of decline (see, e.g. Lévesque and Minniti, 2006).

In their talk, university students constructed different types of stories on entrepreneurship and applied different social and cultural storylines available to them that contained differences in relation to age and gender. Next, we will turn to the three master narratives based on our data: (1) youthful, masculine, startup/growth entrepreneurship, (2) middle aged, feminine, expert entrepreneurship and (3) modest, feminine, senior entrepreneurship. The summary of the master narratives is provided in Table 2. Each master narrative is built around one illustrative example (Aaron's, Leila's and Anni's), which is supported by examples from other interviews to add to the multivoicedness of the analysis.

\section{"They are all young men" - youthful masculine, startup/growth entrepreneurship}

Based on our interview data, we identified the master narrative of youthful, masculine, startup/growth entrepreneurship as being the ideal type of entrepreneurship in the context of Finnish HE. This type of entrepreneurship was considered important as it encourages

Table 2.

Summary of aged and gendered master narratives on entrepreneurship

\begin{tabular}{|c|c|c|}
\hline $\begin{array}{l}\text { Youthful, masculine startup/growth } \\
\text { entrepreneurship }\end{array}$ & $\begin{array}{l}\text { Middle-aged, feminine, expert } \\
\text { entrepreneurship }\end{array}$ & $\begin{array}{l}\text { Modest, feminine senior } \\
\text { entrepreneurship }\end{array}$ \\
\hline $\begin{array}{l}\text { Highly educated special person } \\
\text { seeking challenges }\end{array}$ & $\begin{array}{l}\text { Academically educated and } \\
\text { experienced expert }\end{array}$ & $\begin{array}{l}\text { Humane entrepreneur offering } \\
\text { service and caring for others }\end{array}$ \\
\hline $\begin{array}{l}\text { Energetic, innovative, self- } \\
\text { confident, intelligent, courageous }\end{array}$ & $\begin{array}{l}\text { Systematic and analytical } \\
\text { thinking }\end{array}$ & May be forced entrepreneurship \\
\hline Risk-taking and profit-seeking & $\begin{array}{l}\text { Sensible risk-taking and profit- } \\
\text { making }\end{array}$ & $\begin{array}{l}\text { Involved in working life even in } \\
\text { retirement }\end{array}$ \\
\hline $\begin{array}{l}\text { Growth orientation, hard work and } \\
\text { honesty }\end{array}$ & $\begin{array}{l}\text { Individual values and } \\
\text { autonomy }\end{array}$ & $\begin{array}{l}\text { Work as a basic human good, not } \\
\text { profit-seeking }\end{array}$ \\
\hline
\end{tabular}


"young, highly educated people for entrepreneurship" (Emma [2], 26, business sciences). Leila, 41, business sciences, crystallizes the image of a startup entrepreneur: "They are all young men. And certain kinds of young men." This master narrative was also prominent in our ethnographic study from one EE course that focused on the narratives of experienced entrepreneurs (Komulainen et al., 2020): 16 out of 19 presentations were given by mostly young male entrepreneurs and eight of the male entrepreneurs represented startup entrepreneurship and the majority of the entrepreneurs were growth orientated. Technology and the game industry were the most common business fields among the male entrepreneurs.

In our interview data, only Aaron (28, business studies) positioned himself as a proper risk-taking, growth-orientated entrepreneur, albeit in an existing family business. Others had more modest business goals (see the following two sections). Aaron, the son of a successful and affluent businessman, was in a position to continue the family accounting business and thus optimize an existing business model, instead of creating something novel. This would materialize as a student during his master's studies. His father had also started the accounting business in his youth as a second-year university student. Aaron saw no problem in combining university studies with running a business.

Following in his father's footsteps, Aaron's goal was to become the manager of a growing and prosperous family business and the best accountant in the city. The family support and his father's advice were important in achieving his ambitious goals as an entrepreneur. He had already worked in the family business before starting his studies at university. However, learning in practice was not enough and an academic education was crucial to providing the knowledge and skills needed for an entrepreneur. This is in contrast with previous studies that have highlighted the importance of practical and social competences and skills in entrepreneurship rather than academic achievement and theoretical abilities (Siivonen et al., 2019). The emphasis on academic education may be reflected by accounting being an academic business field, but also Aaron's academic family background.

Aaron constructs the ideal entrepreneur as being "bold and intelligent". He sees a bright future as an entrepreneur due to his natural talent and intelligence:

My future looks rather bright because I'm quite a smart guy. I believe I will most likely do very well. And because my father and sister have done well. To be honest, I'm smarter than either of them and they both agree with this. So, I believe it will work out just fine [ . . ]. (Aaron)

Through the emphasis on his exceptional intelligence, Aaron constructs himself as a special person (Hytti, 2005) who is naturally gifted for entrepreneurship and thus likely to succeed in it. He makes a comparison between himself and his father and sister and states that he is more intelligent than either of them, which confirms the likelihood of his entrepreneurial success. Logico-mathematical intelligence is the prominent prototype of intelligence that is especially attached to men (Räty et al., 2006), which may further accentuate Aaron's confidence in his talent and success.

Aaron also listed qualities such as honesty and hard work as being important assets for an entrepreneur. Honesty and hard work can be interpreted in the framework of the Protestant work ethic (Weber, 1976 (1905)). In a study by Komulainen et al. (2009), hard work was juxtaposed with the modest entrepreneur. However, in Aaron's talk it relates to growthorientated entrepreneurship and a high income: "In this country there is hardly any wage work in which I'd earn enough to satisfy myself [...] I'd like to earn ten thousand euros a month." In the same vein, Kantola and Kuusela (2019) found that Finnish high-income entrepreneurs had learned the value of hard work from home and their success was the result of a combination of passion, entrepreneurial mindset, risk-taking and being a special person.

Aaron also depicted entrepreneurship as more exciting, adventurous, diverse and innovative than wage work: "Wage work is not very exciting. In entrepreneurship you get to try out your own ideas more.” Being an entrepreneur in accounting compensates for the fact 
IJGE

14,1

that Aaron considers accounting, in itself, to be boring. Sebastian, 23, business sciences, summarizes the idea of entrepreneurship as a vocation and not as "normal" work: "You do not necessarily think of it as work, that's what's most important about it."

Aaron describes risk-taking as being a natural part of the fun of being an entrepreneur, and full of adventure, even if you lose money. Like most of the interviewees, he reconstructs risk-taking as a naturally masculine characteristic that is crucial to entrepreneurship:

It's a well-known fact that men are more likely to take risks in general; they drive faster and crash motorbikes more often. I think it's the same in entrepreneurship as there's always a risk of failure and losing money. I believe that testosterone has an effect on this. (Aaron)

The risk-taking dimension carries the assumption that an entrepreneur takes a calculated financial risk but also maximizes profit (Komulainen et al., 2009). According to Kantola and Kuusela (2019), an entrepreneur is like a force of nature who innovates but is also ready to fail and take risks; that's why he is so important for the renewal of the economy. Aaron gave examples of personal risks he had already taken despite his young age. Since the age of 17 he had invested all his savings in stocks. At 18, he bought a detached house on a $100 \%$ loan, which everyone thought was crazy but, according to Aaron, "It all went well". He admitted that having a rich family and "capital" was an advantage in business. Nevertheless, he thought that anyone could become an entrepreneur (see also Siivonen et al., 2019).

Irrespective of age and gender most of the interviewees (re)constructed risk-taking as part of the master narrative of startup/growth entrepreneurship. Most of the interviewees, however, were not ready for even moderate personal risk-taking. Siiri, 28, a student in humanities, expresses the general view: "I'm not ready to take financial risks because I'm the kind of person who plays it quite safe." Entrepreneurship was associated with risk as opposed to wage work, particularly in the public sector, which represented security for most of the interviewees. Risk-taking was generally associated with masculinity and being more natural for males than females:

Yes, I believe there are more men who take risks [.. . ] it's clear that men are more competitive than women $[\ldots]$ if you look at businesses it's clear that there are more men. (Sebastian)

I've realized that damn I'm not ready to take risks myself, but that's it men are somehow more courageous. (Donna, 31, business sciences)

There were, however, also different kinds of voices in the interview data. For example, Laura, 25 , a student in social sciences, stated that she did not see any difference in risk-taking between men and women.

To sum, the master narrative of startup/growth entrepreneurship was associated with youth and masculinity from which femininity was mostly excluded. The youthful figure of a highly educated and self-confident male entrepreneur was dynamic and he was typically involved in a growth-orientated business venture or a startup. For this kind of proper entrepreneur, entrepreneurship was a step in the direction of profit-making and upward mobility in the high-status occupation of an entrepreneur (see also Jones and Warhuus, 2018). Risk-taking growth entrepreneurship was not associated with young females in our data. Similarly, in our ethnographic study (Komulainen et al., 2020) femininity was associated with humane entrepreneurship with modest business goals.

\section{"Knowledge is power" - middle-aged, feminine expert entrepreneurship}

The second master narrative that we identified in our data is middle-aged, feminine expert entrepreneurship. First, it differs from the above youthful, masculine, startup/growth entrepreneurship because of its emphasis on the importance of competence acquired through work experience. In our ethnographic study we also identified the construction of an 
experienced entrepreneur who works hard and accumulates work experience before starting a business (Komulainen et al., 2020). Similarly, in our interview data, Leila, aged 41, a master's student in business sciences, who also has a bachelor's degree from the UAS, and 20 years of work experience, talks about entrepreneurship as a more interesting option in middle age:

Let's say that [.. . I I notice that the negative things related to entrepreneurship diminish. The older I get [... ] and also the competence I have and I realize that, hey, there are quite a lot of things that I know and am able to do. (Leila)

Leila talks positively about age; it has brought her experience, expertise, knowledge and self-confidence. She positions herself as a person who is extremely ambitious, hard-working, active and willing to continually develop and challenge herself: "I've always been very enterprising and very goal orientated at work", "many people have told me that it's stupid to work like that for a stranger." She is not seeking the stability, regularity and security of a permanent position at work, which "would be a nightmare". Education, work experience, expertise and an entrepreneurial mindset make entrepreneurship an option for her in middle age. The probability of engaging in entrepreneurship has been shown to increase with age up to a certain point (usually between 35 and 44 years) and then decrease (Lévesque and Minniti, 2006). The opportunity cost of time increases with age and discourages older individuals from selecting forms of employment that involve risk or deferred gratifications, such as starting a new business (Lévesque and Minniti, 2006).

Second, Leila constructs a sharp difference between entrepreneurship and expert entrepreneurship. According to her, it is important to "be analytical, plan before doing, plan first, count, see, etc. evaluate different options and then decide. In other words, think systematically." She constructs rational, analytical and systematic thinking as being essential to entrepreneurship. She repeats the slogan that "knowledge is power". This is best achieved through academic education:

Those entrepreneurs who have no or very little education. . . [.. . ] they do not analyze anything at all. (Leila)

If I think of the entrepreneurs that I know, most of them had a vocational education. [ . . . ] or very little education. But they had a crazy drive to do all kinds of things, I'm very rational myself but these people are not...they are more like doers and only afterwards do they wonder how things turned out this way. But they've managed unbelievably well. [.. .] Those who attended vocational school drove to the class reunion in Audis and BMWs [. . . ] and those who went to university arrived in their family Toyotas. (Leila)

Leila describes entrepreneurs as being less educated than academically educated expert entrepreneurs. They received a vocational education, if any, and they are constructed as intuitive, non-analytical, passion-driven doers compared to rational and analytical academic thinkers (see also Siivonen et al., 2019). However, vocationally educated doers are positioned as driving Audis and BMWs, suggesting that they have done well financially. Doers and thinkers represent a class-based hierarchy between actionorientated, self-made men and highly educated expert entrepreneurs (see also Gill, 2014). In contrast to prior research (Gill, 2014), formal education does not stifle the capacity for entrepreneurship but makes it analytical and rational, compared to passion-driven action. Prior research has also shown that women consider education as a key factor for success in entrepreneurship (Villasana et al., 2016). However, both passion-driven and analytical entrepreneurs are associated with upward mobility, either financially or socially, and the Protestant ethic of hard work as evidence of a strong moral character (Weber, 1976 (1905); Kantola and Kuusela, 2019).

Third, Leila differentiates between the middle-aged feminine expert entrepreneurship and the chauvinist values of the masculine enterprise culture. She, thus, challenges the 
IJGE 14,1

masculinity of the master narrative of startup/growth entrepreneurship and (re)constucts a master narrative in which also females are included. She justifies her views in a small story about her experiences of gendered entrepreneurship:

Leila: But how chauvinist are these enterprises?

Interviewer: Yes.

L: It's strange where it comes from, that kind of very masculine way of thinking and a chauvinist way of talking, when they come and talk to master's students about their businesses.

I: What is it like?

$\mathrm{L}$ : These businesses have been functioning in very traditional areas. This is how it is presented, all the presentation materials, how the work and employees are talked about. It's all very masculine. And there have been cases in which the talk itself has been chauvinist.

[... .] When the narrative is like "when we blokes went there" and "we blokes did that", and then even if it's not said out loud, you can read between the lines that if there had been a woman, her task would have been to stand there in a miniskirt and high heels.

I: Hm.

L: And to me it sounds like it's not the kind of operating environment in which I'd like to bring in my intensive input.

In the above story, Leila describes masculine enterprise culture as chauvinist, heteronormative and with a familial division of labor representing old-style business masculinity (see also Komulainen et al., 2009). Men have masculine work-related expertise and they do things together, whereas a woman's position is to just "stand there in a miniskirt and high heels" and to appear sexually appealing. Leila distances herself from the values of this kind of enterprise culture and emphasizes social justice. To achieve this, she would need to start her own business with equal and similar-minded partners. This would also enable her to work individually in her own way following her own values as an autonomous, self-governing individual.

Fourth, the middle-aged, feminine master narrative on entrepreneurship does not avoid profit-making and risk-taking if it is sensible:

As an entrepreneur you're able to influence things a lot more, on average. And if you do it well, have a good business idea and do things sensibly, with a reasonable level of risk, you have the possibility to do really well. (Leila)

Entrepreneurship enables independence, autonomy, leadership and creativity; with rational risk-taking, there is also the possibility of great financial success (see also Komulainen et al., 2009). Failure as an entrepreneur would not be the end of the world for Leila as she is in a good socio-economic position: "Personally, I'm in such a fortunate position that I'd have the possibility of starting an enterprise and if I failed it would not be the end of the world."

Most of the interviewees in our data described their prior work experience as being essential to starting a business. Sebastian, 23, a student of business sciences, plans to continue the family business after gaining work experience first: "Like my dad said, pay your learning costs elsewhere and come to work for him after that in earnest." For Alisa, a 24-yearold law student, becoming an entrepreneur is also a future option and "a higher career goal":

It's a long way ahead because I want to acquire work experience first from big firms and all that to broaden my knowledge base before starting a business. If I started a business of my own I would not want to do it right after graduation. (Alisa)

However, Alisa wants to acquire work experience from large firms and broaden her knowledge base before starting her own business. Moreover, she does not want to take high 
risks and would need to have a backup plan as an entrepreneur. Like Leila, she considers expertise and hard work to be important in starting a business that could also be a very reliable and good source of income.

To sum, the master narrative of middle-aged, feminine expert entrepreneurship resists the cultural understandings of youthfulness and masculinity related to startup/growth entrepreneurship. Instead, the master narrative of middle-aged, feminine expert entrepreneurship is constructed as available for females. Moreover, it is associated with experience and expertise, thus, (re)constructing the probability of engaging in entrepreneurship in middle age (Lévesque and Minniti, 2006).

\section{"Life, here I come" - modest, feminine senior entrepreneurship}

The third master narrative on entrepreneurship that we identified in our data is modest, feminine senior entrepreneurship. In our interview data, Anni, 65, a student of administrative sciences, explicitly states that entrepreneurship is the only way to become employed at "this age":

Interviewer: I wanted to ask about what this university education and being academically educated means to you?

Anni: Well, it means a totally new life. And, again, I'm enthusiastic here. Because I'm this age, in order to benefit from this education, I'll have to bring my entrepreneurship to life. I'll probably start off with a trade name and, as I'm this old, I will not be liable for pension payments for entrepreneurs.

I: Oh, does that sort of thing exist?

A: Yes, you see, once you've retired, at the retirement age, you do not need to keep paying those pension payments. You know, they are several hundred euros a year.

Becoming an entrepreneur after her graduation from university would enable Anni to continue working: "Life, here I come. Anything is still possible." In the same vein, Linnea, 50, a student of social pedagogics, thinks that forced entrepreneurship may be the only option left for her:

I just turned 50 and age discrimination is a fact, there is no guarantee that I will find a job, [. . . I wonder if it'll be forced entrepreneurship if I'm left with no other options? (Linnea)

Although employees in Finland have the option of working until the age of 68, based on her recruitment study, Vaahtio (2003) argues that working life age in Finland is 55, after which employability decreases and employment prospects weaken. For older workers, entrepreneurship may be the only option to stay actively involved in working life. In the study by Ainsworth and Hardy (2008), older workers were most often constructed as small business purchasers trying to buy themselves a job rather than hierarchically more valued small business starters. Moreover, their small business purchases were criticized as being simultaneously too low risk (they were seen as seeking security) and too high risk (they were seen as gambling away their redundancy packages). Paradoxically, however, entrepreneurship is also offered to older people in order to prolong their careers and stay actively involved in working life, even after retirement.

The neoliberal imperative constructs "narratives of progress" and citizens who are actively engaged in continuing to learn and develop themselves also at retirement age. As an entrepreneur, Anni plans to offer feminine services and care for others at a low cost. For her, entrepreneurship "has to do with helping people" and not charging too much: 
IJGE

14,1

Yes, and then I do not need to charge as much as lawyers. 275 euros per hour, ... My goodness, anyway I see myself there at a grassroots level with people. . . (Anni)

Anni makes herself attractive as an entrepreneur by not charging too much. This way she is able to be (re)productive by offering services and caring for others. She also positions herself as working class and "at a grassroots level with people"; her potential clients who would need legal support. In the same vein, Victoria, 37, social sciences, thinks of entrepreneurship as a future option, but in her field "your heart has to be in this work, so that you do not think of money [... ] and how to manage financially, it's more to do with thinking about your clients and what you can offer them."

The modest, feminine, senior master narrative on entrepreneurship can be interpreted as non-profit-seeking entrepreneurship that relates to gendered work ethics and charging less than others (men). This master narrative, thus, challenges profit-seeking as a business goal related to the master narratives of startup/growth entrepreneurship and expert entrepreneurship, and (re)constructs modest feminine entrepreneurship (Hytti and Heinonen, 2013) as the option available for older females. Also, two female entrepreneurs in our ethnographic data represented humane entrepreneurship with modest business goals that contribute to the general good (see also Komulainen et al., 2020).

\section{Discussion and implications}

This study examines entrepreneurship critically as a naturalized, normalized and neutralized individualistic neoliberal discourse accessible for all university students across all disciplines as a freely chosen occupational choice (Gill, 2014). Prior studies have shown that entrepreneurship is a masculine construction to which only a few special individuals have access (see e.g. Hytti and Heinonen, 2013; Jones, 2015). So far, however, research on age, gender and entrepreneurship in the context of $\mathrm{EE}$ and $\mathrm{HE}$ has been virtually non-existent. The Finnish university provides a fruitful context to study age and entrepreneurship in particular as students and graduates in Finland represent different age groups (Lindberg, 2009).

In this study we set as our task to ask (1) What kinds of master narratives are (re) constructed in relation to age and entrepreneurship by Finnish university students? (2) How does gender intertwine with age in the construction of entrepreneurship? Based on our analysis of 30 student interviews that were generated in the context of $\mathrm{EE}$ and Finnish $\mathrm{HE}$ we identified three aged and gendered master narratives on entrepreneurship: (1) youthful, masculine startup/growth entrepreneurship; (2) middle-aged, feminine, expert entrepreneurship and (3) modest, feminine senior entrepreneurship.

The highly educated, self-confident youthful male entrepreneur of the startup/growth master narrative was constructed as the ideal and proper entrepreneur in our data (see also Komulainen et al., 2009; Hytti and Heinonen, 2013; Jones, 2015). The master narrative of startup/growth entrepreneurship was also prominent in our ethnographic study that was conducted in the same community (Komulainen et al., 2020). This gives us grounds to argue that the youthful masculine startup/growth entrepreneurship is the hegemonic master narrative on entrepreneurship in the context of EE and Finnish HE. For this kind of proper entrepreneur, entrepreneurship is a step in the direction of profit-making and upward mobility (see also Komulainen et al., 2009). Young females are marginalized or altogether excluded from this master narrative of entrepreneurship as they are not associated with risktaking and profit-seeking constructed as essential in startup/growth entrepreneurship (see also Jones, 2015).

Middle-aged, feminine expert entrepreneurship takes place at the peak of one's career (see also Lévesque and Minniti, 2006). Academic education and work experience acquired in wage 
work produce the competence, knowledge and self-confidence needed in expert entrepreneurship. Middle-aged, feminine expert entrepreneurship makes it possible to work in one's own way and according to one's own values against the hegemonic, masculine enterprise culture. The middle-aged feminine, expert entrepreneurship resists the cultural understandings of youthfulness and masculinity related to startup/growth entrepreneurship and (re)constructs entrepreneurship that is available for females and in middle age. It involves risk-taking and profit-seeking, but in a sensible way. This is in line with the neoliberal individualistic discourse of the freedom to make one's own kind of entrepreneurship based on one's own personality and search for meaning and autonomy at work (see also Siivonen et al., 2019).

Senior female entrepreneurship is modest, feminine service and caring for others. It may be forced entrepreneurship and the only way of becoming employed at an older age. The value of work is seen as a basic human good; not the accumulation of material wealth but the fulfillment of one's calling (Komulainen et al., 2009). The neoliberal imperative constructs a "narrative of progress" and citizens who are also actively engaged in continuing to learn and develop themselves at retirement age. Active involvement in working life has become an imperative even in retirement, and entrepreneurship is encouraged as an option for becoming employed at an older age to prolong careers and prevent early retirement (Ainsworth and Hardy, 2008; Tomlinson and Colgan, 2014; Kautonen et al., 2017). However, in contrast to startup/growth and expert entrepreneurship senior entrepreneurship is labeled as "modest" and, thus, undermined in terms of economic growth (see also Whiting and Pritchard, 2020).

The theoretical and methodological approach of this study on master narratives is novel and contributes to critical EE literature in the context of $\mathrm{HE}$ in an important way. Master narratives identified through narrative positioning analysis make visible, how entrepreneurship is viewed and talked about by university students in the context of EE and Finnish HE. Aged and gendered master narratives on entrepreneurship create and limit how life ought to be lived in the culture, i.e. produce normative cultural expectations (Phoenix, 2008). The master narratives identified in this study show that HE students are not addressed equally in relation to entrepreneurship, but aged and gendered hierarchies are sustained. This has unforeseen consequences for different aged female and male HE students and graduates.

As our study indicates entrepreneurship is offered as a future career option for different aged $\mathrm{HE}$ students and graduates. However, entrepreneurship as a gendered construction is sustained as females are altogether excluded from the category of an ideal and proper startup/growth entrepreneur (see also Jones, 2015). The cultural understandings available to females comprise middle-aged expert entrepreneurship and modest senior entrepreneurship, to which young females may not readily relate. The false promise of entrepreneurship as a future career option for all denies the collective subordination that constrains and undermines young and older women's entrepreneurial propensity and achievements (see also Whiting and Pritchard, 2020; Ahl and Marlow, 2021). This is also reflected in entrepreneurial intent, which has been shown to be more common for males than females in Finland (Räty et al., 2019).

Moreover, as our study confirms entrepreneurship is not only an aged and gendered construction, it is also an individualistic neoliberal discourse that responsibilizes HE students and graduates for their own employability in the uncertain world of work (see e.g. Siivonen et al., 2019). They become responsible for employing themselves and others in order to have a positive impact on the economy (Laalo et al., 2019). The individualistic discourse emphasizes personal gains, such as employability, whereas transforming working life and creating graduate-level jobs demands collective and societal effort (Siivonen et al., 2019).

In $\mathrm{HE}$ policy as well as in $\mathrm{EE}$ it is important to challenge the aged and gendered constructions of entrepreneurship and create more inclusive master narratives on 
IJGE

14,1

entrepreneurship. Startup/growth entrepreneurship is a restrictive version of entrepreneurship that many HE students do not readily relate to Komulainen et al. (2020). A broader spectrum of different types of entrepreneurship would potentially open up avenues for a larger number of different aged female and male $\mathrm{HE}$ students and graduates. However, as our study confirms not all HE students perceive entrepreneurship as a future career option as academic wage work represents security for them (Komulainen et al., 2019). This should also be acknowledged in HE policy that promotes entrepreneurship and EE for all students across disciplines.

\section{Conclusion}

This study addresses an important gap in the critical literature on entrepreneurship as an aged as well as gendered phenomenon in the context of EE and HE. The study makes visible how entrepreneurship as a fairly novel master narrative promoted through $\mathrm{EE}$ in $\mathrm{HE}$ reproduces and strengthens structural inequalities in the society. Female university students are excluded from the male-dominated master narrative of startup/growth entrepreneurship that has higher earning potential and a possibility for upward mobility. The aged and gendered master narratives (re)constructed by Finnish university students have evident consequences on how different aged female and male university students perceive themselves and their future careers. This is in sharp contrast with the task of promoting equality in the Finnish HE system that still follows the Nordic welfare state model (VuorinenLampila, 2016).

We argue that aged and gendered master narratives on entrepreneurship direct different aged male and female university students toward segregated positions and pathways in $\mathrm{HE}$ and working life. This is likely to take place also outside Finland as entrepreneurship and EE have been shown to be male dominated arenas also elsewhere (e.g. Rae et al., 2012). This further strengthens gender segregation in education and working life, which has been shown to be especially strong in Finland in international comparison (Vuorinen-Lampila, 2016).

We acknowledge that the HE students' elaborations on entrepreneurship, age and gender varied in length and detail. Nevertheless, also those students who did not consider entrepreneurship as a career option for themselves (re)constructed the master narratives that we identified in this study by distancing or resisting them. In future research there is a need to study how entrepreneurship is lived out by female and male university graduates of different ages in different national contexts. This would make visible their subjective experiences as entrepreneurs in different narrative environments.

\section{Notes}

1. UASs (Universities of Applied Sciences) concentrate on providing professional and vocational education. The research profile of UASs is regional development and thus complementary to universities.

2. To protect the anonymity of the participants, pseudonyms have been used to refer to the interviewees.

\section{References}

Ahl, H. and Marlow, S. (2021), "Exploring the false promise of entrepreneurship through a postfeminst critique of the enterprise policy discourse in Sweden and the UK", Human Relations, Vol. 74 No. 1, pp. 41-68.

Ainsworth, S. and Hardy, C. (2008), "The enterprising self: an unsuitable job for an older worker", Organization, Vol. 15 No. 3, pp. 389-405. 
Akava (2016), "Mitä korkeakoulutetut nuoret haluavat tulevaisuuden työelämältä [Highly-educated young people want stability from their working life]", available at: https://www.akavalainen.fi/ akavalainen/arjessa/tyoelamassa/mita_korkeakoulutetut_nuoret_haluavat_tulevaisuuden_ tyoel amalta (accessed 15 January 2020).

Anthias, F. (2005), "Social stratification and social inequality: models of intersectionality and identity", in Devine, F., Savage, M., Scott, J. and Crompton, R. (Eds), Rethinking Class, Culture, Identities and Lifestyles, Palgrave Macmillan, Houndsmills, pp. 24-45.

Bacigalupo, M., Kampylis, P., Punie, Y. and Van den Brande, L. (2016), "EntreComp: the entrepreneurship competence framework. Publication Office of the European Union", available at: https://ec.europa.eu/jrc/en/publication/eur-scientific-and-technical-researchreports/entrecomp-entrepreneurship-competence-framework (accessed 14 August 2020).

Bamberg, M. (1997), "Positioning between structure and performance", Journal of Narrative and Life History, Vol. 7 Nos 1-4, pp. 335-342.

Bamberg, M. (2004), "Form and functions of 'slut bashing' in male identity constructions in 15-yearolds", Human Development, Vol. 47 No. 6, pp. 331-353.

Bamberg, M. and Georgakopoulou, A. (2008), "Small stories as a new perspective in narrative and identity analysis", Text and Talk, Vol. 28 No. 3, pp. 377-396.

Berglund, K. (2013), "Fighting against all odds: entrepreneurship education as employability training", Ephemera, Vol. 13 No. 4, pp. 717-735.

Brine, J. (2006), "Lifelong learning and the knowledge economy: those that know and those that do not-the discourse of the European Union”, British Educational Research Journal, Vol. 32 No. 5, pp. 649-665.

Byrne, J., Fattoum, S. and Dias Garcia, M.C. (2019), "Role models and women entrepreneurs: entrepreneurial superwoman has her say", Journal of Small Business Management, Vol. 57 No. 1, pp. 154-184.

Dahlstedt, M. and Hertberg, F. (2012), "Schooling entrepreneurs: entrepreneurship, governmentality and education policy in Sweden at the turn of the millennium", Journal of Pedagogy, Vol. 3 No. 2 , pp. 242-262.

De Fina, A. (2013), "Positioning level 3: connecting local identity displays to macro social processes", Narrative Inquiry, Vol. 23 No. 1, pp. 40-46.

European Commission (2008), "Entrepreneurship in higher education, especially within non-business studies. Final report of the expert group", available at: https:/ec.europa.eu/growth/content/ final-report-expert-group-entrepreneurship-higher-education-especially-within-non-business-0_ en (accessed 13 August 2020).

Farny, S., Frederiksen, S.H., Hannibal, M. and Jones, S. (2016), "A CULTure of entrepreneurship education”, Entrepreneurship and Regional Development, Vol. 28 Nos 7-8, pp. 514-535.

Gill, R. (2014), "If you're struggling to survive day-today': class optimism and contradiction in entrepreneurial discourse", Organization, Vol. 21 No. 1, pp. 50-67.

Gubrium, J.F. and Holstein, J.A. (2008), "Narrative ethnography", in Hesse-Biber, S.N. and Leavy, P. (Eds), The Handbook of Emergent Methods, Guilford Publications, New York, pp. 241-264.

Gullette, M.M. (2003), "From life storytelling to age autobiography", Journal of Aging Studies, Vol. 17 No. 1, pp. 101-111.

Heinonen, J. and Hytti, J. (2010), "Back to basics: the role of teaching in developing the entrepreneurial university", Entrepreneurship and Innovation, Vol. 11 No. 4, pp. 283-292.

Hyrkäs, A. (2016), "Startup complexity: tracing the conceptual shift behind disruptive entrepreneurship", available at: https://helda.helsinki.fi/handle/10138/170030 (accessed 20 August 2020).

Hytti, U. (2005), "New meanings for entrepreneurs: from risk-taking heroes to safe-seeking professionals", Journal of Organizational Change and Management, Vol. 18 No. 6, pp. 594-611.

Hytti, U. and Heinonen, J. (2013), "Heroic and humane entrepreneurs: identity work in entrepreneurship education”, Education + Training, Vol. 55 Nos 8/9, pp. 886-898. 
IJGE 14,1

Jones, S. and Warhuus, J.P. (2018), "'This class is not for you': an investigation of gendered subject construction in entrepreneurship course descriptions", Journal of Small Business and Enterprise Development, Vol. 25 No. 2, pp. 182-200.

Kantola, A. and Kuusela, H. (2019), Huipputuloiset. Suomen Rikkain Promille [Top-Income Earners. The Richest Per Mille in Finland], Vastapaino, Tampere.

Kautonen, T., Tornikoski, E. and Kibler, E. (2011), "Entrepreneurial intentions in the third age: the impact of perceived age norms", Small Business Economics, Vol. 37 No. 2, pp. 219-234.

Kautonen, T., Kibler, E. and Minniti, M. (2017), "Late-career entrepreneurship, income and quality of life", Journal of Business Venturing, Vol. 32 No. 3, pp. 318-333.

Komulainen, K. (2006), "Neoliberal educational policy: a case study of Finnish textbooks of entrepreneurial education", Nordisk Pedagogik, Vol. 26, pp. 212-228.

Komulainen, K., Korhonen, M. and Räty, H. (2009), "Risk-taking abilities for everyone?", Finnish Entrepreneurship Education and the Enterprising Selves Imagined by Pupils. Gender and Education, Vol. 21 No. 6, pp. 631-2649.

Komulainen, K., Hirvonen, I., Kaskes, K., Kasanen, K. and Siivonen, P. (2019), “Asiantuntijoita, monitaitoisia ja akateemisia yrittäjiä. Yliopisto-opiskelijoiden asemoituminen akateemisuuteen, työllistettävyyteen ja yrittäjyyteen [Experts, multitalents and academic entrepreneurs University students positioning to being an academic, employability and entrepreneurship]", Aikuiskasvatus, Vol. 39 No. 2, pp. 122-137.

Komulainen, K., Siivonen, P., Kasanen, K. and Räty, H. (2020), “How to give a killer pitch?' Performances of entrepreneurial identities in higher education", Entrepreneurship Education and Pedagogy, Special Issue: 'Unsettling Entrepreneurship Education', Vol. 3 No. 3, pp. 214-235.

Laalo, H., Kinnari, H. and Silvennoinen, H. (2019), "Setting new standards for homo academicus: entrepreneurial university graduates on the EU agenda", European Education, Vol. 51 No. 2, pp. 93-110.

Lévesque, M. and Minniti, M. (2006), "The effect of aging on entrepreneurial behavior", Journal of Business Venturing, Vol. 21 No. 2, pp. 177-194.

Lewis, K.V. (2017), "Making meaning as well as money: the experience of young female entrepreneurs", International Journal of Gender and Entrepreneurship, Vol. 9 No. 4, pp. 377-391.

Lindberg, M.E. (2009), "Student and early career mobility patterns among highly educated people in Germany, Finland, Italy and the United Kingdom”, Higher Education, Vol. 58, pp. 339-358.

Mallet, O. and Wapshott, R. (2015), "Making sense of self-employment in late career: understanding the identity work of olderpreneurs", Work, Employment and Society, Vol. 29 No. 2, pp. 250-266.

Ogbor, J.O. (2000), "Mythicizing and reification in entrepreneurial discourse: ideology-critique of entrepreneurial studies", Journal of Management Studies, Vol. 37 No. 5, pp. 605-635.

Phoenix, A. (2008), "Analysing narrative contexts", in Andrews, M., Squire, C. and Tamboukou, M. (Eds), Doing Narrative Research, Sage, London, pp. 65-77.

Räty, H., Kasanen, K. and Kärkkäinen, R. (2006), "School subjects as social categories", Social Psychology of Education, Vol. 9 No. 1, pp. 5-25.

Räty, H., Komulainen, K., Hytti, U., Kasanen, K., Siivonen, P. and Kozlinska, I. (2019), "University students' perceptions of their abilities relate to their entrepreneurial intent", Journal of Applied Research in Higher Education, Vol. 11 No. 4, pp. 897-909. 
Rae, D., Lynn, M., Antcliff, V. and Hannon, P. (2012), "Enterprise and entrepreneurship in English higher education: 2010 and beyond", Journal of Small Business and Enterprise Development, Vol. 19 No. 3, pp. 380-401.

Reay, D. (2006), "The zombie stalking English schools: social class and educational inequality”, British Journal of Educational Studies, Vol. 54 No. 3, pp. 288-307.

Aged and gendered master narratives

Siivonen, P. and Brunila, K. (2014), "The making of entrepreneurial subjectivity in adult education", Studies in Continuing Education, Vol. 36 No. 2, pp. 160-172.

Siivonen, P. and Isopahkala-Bouret, U. (2016), “Adult graduates' negotiations of age(ing) and employability”, Journal of Education and Work, Vol. 29 No. 3, pp. 352-372.

Siivonen, P., Peura, P., Hytti, U., Kasanen, K. and Komulainen, K. (2019), "The construction and regulation of collective entrepreneurial identity in student entrepreneurship societies", International Journal of Entrepreneurial Behaviour and Research, Vol. 26 No. 3, pp. 521-538.

Skeggs, B. (1997), Formations of Class and Gender: Becoming Respectable, SAGE, London.

Skeggs, B. (2005), "The making of class and gender through visualizing moral subject formation", Sociology, Vol. 39 No. 5, pp. 965-982.

Tomlinson, F. and Colgan, F. (2014), "Negotiating the self between past and present: narratives of older women moving towards self-employment", Organization Studies, Vol. 35 No. 11, pp. 1655-1675.

Vaahtio, E.-L. (2003), “'Työmarkkinaikää ei lasketa kalenterista. Tutkimus rekrytoinnista, iästä ja ageismista' [Working life age is not marked in the calendar. A study on recruitment, age, and ageism]", Journal of Työpoliittinen Aikakauskirja, Vol. 2, pp. 42-56.

Villasana, M., Alcarez-Rodríguez, R. and Alvarez, M.M. (2016), "Examining entrepreneurial attributes of Latin American female university students", Gender and Education, Vol. 28 No. 1, pp. 148-166.

Vuorinen-Lampila, P. (2016), "Gender segregation in the employment of higher education graduates", Journal of Education and Work, Vol. 29 No. 3, pp. 284-308.

Weber, M. (1976 (1905)), The Protestant Ethic and the Spirit of Capitalism, 1st ed., Allen and Unwin, London.

Whiting, R. and Pritchard, K. (2020), "Reconstructing retirement as an enterprising endeavor", Journal of Management Inquiry, Vol. 29 No. 4, pp. 404-417.

Yukongdi, V. and Lopa, N.Z. (2017), "Entrepreneurial intention: a study of individual, situational and gender differences", Journal of Small Business and Enterprise Development, Vol. 24 No. 2, pp. 333-352.

\section{Corresponding author}

Päivi Tuulikki Siivonen can be contacted at: paivi.siivonen@uef.fi

For instructions on how to order reprints of this article, please visit our website:

www.emeraldgrouppublishing.com/licensing/reprints.htm

Or contact us for further details: permissions@emeraldinsight.com 